\title{
The development of theoretical and practical didactic fundamentals in the ukrainian school: sava chavdarov
}

\author{
O. V. Plakhotnik ${ }^{1}$, A. Y. Kuzmenko ${ }^{2}$ \\ ${ }^{1}$ Taras Shevchenko National University of Kiev, Kyiv, Ukraine \\ ${ }^{2}$ Department of History and Philosophy of Education, Institute of Pedagogy of the National Academy of Sciences of Ukraine, Kyiv, \\ Ukraine \\ Corresponding author. E-mail: olgaplakhotnik@hotmail.com, kuzanya@i.ua
}

Paper received 10.12.20; Accepted for publication 22.12.20.

https://doi.org/10.31174/SEND-HS2020-242VIII42-09

\begin{abstract}
The article deals with a prominent Ukrainian scientist, teacher, didactic specialist and methodologist Sava Khrystoforovych Chavdarov. In his textbooks S. Chavdarov makes an attempt to justify the system of language education in Ukrainian schools from the first to the tenth grade inclusively. As a methodologist, he outlined the principles of building a school grammar course in high school in the programs and textbooks, gave guidelines for their coverage.

Keywords: educational activity of S. Kh. Chvadarov, theory and practice of teaching, didactic heritage, improvement of forms and methods of teaching.
\end{abstract}

Introduction. The first half of the XX century in Ukraine was characterized by instability, contradictory trends, shifting worldviews, reorientation of values and priorities the main factors of which were global socio-political and cultural-educational processes in the country which significantly affected various spheres of society.

The education sector was not an exception. Therefore, the formation and development of pedagogical science of the outlined period has been considered taking into account significant socio-historical and socio-cultural changes. At that time, it was not so much about the problem of technicalization of life (for example, electrification) that became especially relevant but it was the problem of its domestication, the creation of a humane society, the formation of positive thinking in people, constructive behavior, consciousness and responsibility that were really urgent. The above mentioned qualities remain relevant today. Therefore, taking into account the peculiarities of the situation, the need for a theoretical study of the past historical experience in the field of education and upbringing is a priority task. This is especially concerns higher education, since it is higher education where the biggest gaps in modern pedagogical practice are observed. From this point of view, it is important to analyze the activities of prominent scientists and educators of the past. Persistent searches for methods to solve important pressing problems inevitably lead to historical analogies. An important place in historical and pedagogical research is occupied by the study of the achievements of a unique cohort of Ukrainian public figures of the XIX and XX centuries who took the most active part in the formation of the Ukrainian system of education and upbringing.

Brief overview of related publications. Due to the above, it is important to study, analyze, summarize and creatively use the current ideas of those Ukrainian teachers as well as cultural and educational figures who have made a significant contribution to the development of Ukrainian pedagogical science and practice. Without knowledge of how the theory and practice of national education and school have developed in the past, without understanding and rethinking of Ukrainian pedagogical experience, which does not only enriches modern pedagogical science with new facts and theoretical provisions but also allows to predict its future development, it is absolutely impossible to deal with the issue. The works of famous Ukrainian teachers G. Vashchenko, B. Hrinchenko, M. Drahomanov, O. Konysky, T. Lubents, V. Naumenko, I. Ogienko, S. Rusova, S. Siropolko, J. Chepiga, S. Cherkasenko and other world-renowned scientists have become a valuable heritage of Ukrainian pedagogical science and education.

Their educational heritage was introduced into a wide scientific circle by historical and pedagogical investigations of such modern Ukrainian researchers as A. Aleksyuk, N. Antonets, L. Vovk, N. Gupan, N. Dichek, N. Kalenichenko, E. Kovalenko, V. Mayboroda, O.Plakhotnik, O.Savchenko, I.Skoropad, M.Stelmakhovych, O. Sukhomlynska and others.

The life and scientific achievements of the teachers from the past who have made considerable efforts to develop and reform education is being actively studied today. However, the contribution of the pedagogical heritage of significant names of scientists and teachers, which need a thorough study and presentation to the pedagogical community of the XXI century, has not been sufficiently studied.

Among the outstanding Ukrainian scientists-teachers and methodologists of the late XIX - early XX century an important place is occupied by the figure of Sava Khristoforovich Chavdarov (1892-1962).

The name of this scientist is widely known not only in Ukraine but also abroad. S. Chavdarov was one of the founders of the science of pedagogy and organization of school work. He is the author of deeper works on the history of pedagogy, didactics, textbooks and manuals.

The purpose of the article is to make a contribution to pedagogical knowledge by analyzing the creative work of $\mathrm{S}$. Chavdarov as an evidence of the development of pedagogical theory and practice in the second third of the twentieth century, who being based on the methodology of $\mathrm{J}$. Comenius, K. Ushinsky and other teachers of Ukrainian and foreign pedagogy in their direct relationships and interdependencies, substantiated the system of language education in schools of Ukraine.

Research methods. Search and bibliographic method of the study and analysis of scientific literature, which allowed to identify the source base of scientific and pedagogical heritage of S. Chavdarov; biographical method used to analyze the life of the scientist; problem-chronological method which was used in the consideration of scientific 
and pedagogical activity of S. Chavdarov in chronological order; the method of retrospective logical-semantic analysis which was used to select factual material in order to clarify the data of the scientist's life; classification, systematization and modeling of informatio which contributed to the disclosure and justification of scientific and pedagogical activities of the scientist; comparison and generalization of research results which allowed to analyze the theoretical approaches of S. Chavdarov to the organization of the educational process and evaluate its contribution to pedagogical science.

Research materials. The works of S. Chavdarov which include textbooks, manuals, monographs, scientific and journalistic articles, reports, reviews, reports, programs and materials of journalistic publications. Valuable factual material was collected during the processing of information materials in the Scientific Library named after $M$. Maksymovych of Taras Shevchenko National University of Kyiv, the State Scientific and Pedagogical Library of Ukraine named after V. Sukhomlynsky, the Pedagogical Museum of the Academy of Pedagogical Sciences of Ukraine, the National Library of Ukraine named after V. Vernadsky. Technical Library of Ukraine, Scientific and Reference Library of the Central State Archive of Ukraine, the State Archives of Kyiv, the Central State Archive of Higher Authorities and Administration of Kyiv, the Central State Historical Archive of Ukraine. The collections of normative documents, socio-political and pedagogical press, reference and bibliographic literature, historical and pedagogical researches as well as book and article bibliographic lists, sources of dissertation researches, Internet resources, etc. were used.

Results and discussions. S.Chavdarov's scientific and pedagogical heritage includes monographs, textbooks for students of pedagogical educational institutions and schools, articles, reports, lectures, etc. They still arouse undoubted theoretical and practical interest among researchers of the problems of state language education and speech development of schoolchildren.

The analysis of S.Chavdarov's scientific work shows that he focused on the work of such prominent teachers of the past as A.Disterweg, J. Komenskiy, K. Ushinsky and his contemporaries - P.Afanasyev, L.Bulakhovsky, O. Biletsky, V. Pomagayba, O. Peshkovsky, D. Ushakova and others.

Not only many pedagogical problems are widely covered in S.Chavdarov's researches, but also the experience of the development of the Ukrainian pedagogy is deeply generalized. They are distinguished by the desire for a holistic disclosure of the processes of forming the students personality. Today we consider the pedagogical heritage of S.Chavdarov to be not only a milestone in the history of pedagogical thought in Ukraine, but also as an important source in solving modern problems of teaching and educating students.

Professor S.Chavdarov made a significant contribution to the development of the teaching theory, in particular the forms and methods of teaching in both secondary and higher education.

Having comprehended the experience of the development of Ukrainian and foreign pedagogy, the scientist created his own one on which his methodology of teaching the Ukrainian language is based. The essence of this system is, first, an organic combination of different aspects of learning the Ukrainian language - phonetics, vocabulary, word formation, grammar and style; secondly, in the application of effective forms of education (lesson, extracurricular activities, excursions, etc.); third, in the teacher and student cooperation (heuristic conversation, observation of the language, teacher's evidence, the work with the textbook, exercises).

At S.Chavdarov's height of scientific and pedagogical activity (early 1920s), numerous documents which reflected the conceptual provisions of the new school appeared, the most important of which was teaching in the native language. This problem has become one of the leading in the scientific work of the famous teacher.

In 1920 along with Russian the Ukrainian language was proclaimed to be an official language of republican's state bodies. The decree which obliged schools and state bodies to use the mother tongue was issued on September 21st.

Lately, learning the Ukrainian language was fully included in the curriculum of different types of schools. The content of language learning wasn't defined yet as well as the methods of teaching. Consequently, for the scholar, these were the years of searching. His keen interest in the methodology of teaching the Ukrainian language began to show itself at that period. Nevertheless, he had to face serious problems such as to acquaint a great number of teachers with the institutional basis of the Ukrainian language, to inform them of the latest methodological novelties and finally to define specific aspects of teaching Ukrainian.

S.Chavdarov became the promoter of new methodological ideas. He was among those scholars, who would speak out against tendencies to hinder the development of Ukrainian language, devaluation of artistic expression in schools and also against excessive use of written business language along with a lack of grammar studying and ignorance of the need to correct students' mistakes. Pedagogic theory, examining and summarising the experience of educational practitioners and experimentation were what the scholar considered as fundamental principles of methodology formation.

In the early 1930s, S.Chavdarov was actively engaged in research work which he managed to combine with teaching in higher educational institutions.

After the order "On implementation of the universal primary school education in Ukraine" had been issued in August 1930 S.Chavdarov wrote several articles for some journals, for instance, "Punctuation technique of labour schools" [2], "Further challenges in teaching languages" [3], in which he pointed out that the language was not being properly taught in schools, the essence of spelling changes was not described, and also there was no systematic way of assessing students' grammar skills, linguistic culture, and, above all, the work on the classification of orthographic, punctual and pronunciation was not performed.

In January 1932, S.Chavdarov, working already in Kyiv branch of the Ukrainian Research Institute of Pedagogy as the head of the department of language and literature methodology of the Institute of Pedagogy, was trying to create official Ukrainian language textbooks for primary school. In the textbook, he laid out clearly, logically and cohesively the material from the definition of "The arrangement between words in sentences" to the study of parts of speech 
(third grade), whereas in the fourth grade it was supposed to continue studying sentences, verbs, word formation. The titles of the photographs were interesting: "Exclamation words", "Spelling of appendages", which are not inherent in modern terminology of Ukrainian language textbooks.

In the same year, in 1934, together with P. Volynsky, he created a manual for teachers "How to teach grammar and spelling of the Ukrainian language in a primary school with the Ukrainian language of instruction (according to the official textbook of S.Chavdarov and P.Volynsky)" [8], approved and published by the State Publishing House "Soviet School". In the section "General attention to work with the textbook of the Ukrainian language for primary school," it was noted that "the textbook provides the material for the systematic examination of the grammar and spelling programs". At the same time, the material outlined in the textbook also contributed to the development of oral and written language. According to it, working on grammar and spelling was closely related to the improvement of students' vocabulary, clarifying of their speech and development of their self-expression skills [1,p. 3]. Apart from that, it was recommended by the authors to use a special selection of drawings from the book "Pictures on the development of oral and written speech", "Uchpedgiz", 1933 [1,p. 3].

As we can see, S.Chavdarov's work was necessary for Ukrainian schools, for there was a lack of scientific and methodological literature published in the Ukrainian language. Moreover, it did not have a large circulation. Sava Khrystoforovych became the author of the textbooks "Ukrainian language" for 1, 2, 3, 4 grades of primary and eight-year school, textbooks for 1, 2, 3, 4 grades of schools for the visually impaired students. Most of them undergone about 30 reprints. S. Chavdarov tried to reveal the most pressing issues of education and upbringing of the younger generation. According to his textbooks, children studied in Ukrainian schools for about forty years.

Creating his textbooks, S.Chavdarov would work hard to improve the methodology of teaching the native language. On the pages of professional publications, the scientist analyzes the existing shortcomings that exist in the teaching of not only language but also other subjects. Moreover, he considered the problem of the development of oral and written speech of children. These works became the basis for such well-known works as: "Methods of teaching the Ukrainian language in primary school" (1937) and "Methods of teaching the Ukrainian language (grammar and spelling) in high school" (1939) [4-5].

In his textbooks S.Chavdarov tries to justify the system of language education in schools of Ukraine from the first to the tenth grade. He considered the methodological foundations and practical tasks of language learning, noted the need for systematics, accurate delineation of knowledge, strong skills, pointed to the links between language learning and children's thinking; outlined the principles of providing a school grammar course in high school, provided guidelines for language teaching. "Methods of teaching the Ukrainian language (grammar and spelling) in high school" [6] was republished many times and until 1955 remained providing teachers with a constant help.

The problem of the Ukrainian language lesson, which gives impetus to the development of teaching methods in other disciplines was the subject of Professor S. Chavda- rov's special attention.

In 1949, a great influence on the development of teaching methods was made by the scientist's book "Principles of Soviet Didactics" [5] in which he defended the system of didactic principles.

The publication of this book became a notable phenomenon in the pedagogical life of Ukrainian Republic. It was a fundamental work devoted to the extremely important issue of pedagogical science in the organization of the educational process at school. In this work, the author presented a well-founded system of didactic principles of Soviet pedagogy and science.

The great achievement of the author was that at that time this issue did not get a proper solution. In the interpretation of didactic principles, the habit remained only to repeat the vision of this issue by teachers of the past. In his work, S. Chavdarov paid great attention to the solution of the content and classification of didactic principles by Herbart, Spencer, Dewey, Thorndike. The relevance of the characteristics of the didactic principles of these famous theorists, which are presented in the book by S. Chavdarov, retain their significance to this day [9, p.327].

Based on the educational objectives of the then Soviet school, the author defines such principles of didactics as: communist ideology, science, conscious assimilation of knowledge, connection of theory with practice in the educational process, clarity, strength of students' knowledge, taking into account general and individual age features of mental development, leading role of the teacher in the educational process.

This work of S.Chavdarov was the only one monographic publication of that period on the problem of the principles of Soviet didactics. In his later works, the author wrote that he would like to deepen and rethink his work "Principles of Soviet didactics" and prepare a book to help the teacher on improving teaching methods in school, taking into account the Law on School and its requirements for improving the educational process.

It should be noted that S.Chavdarov was a human of his time, but in his theoretical legacy there were many ideas and methodological developments, which today have not lost their significance.

Another important milestone in the pedagogical work of the scientist was the order of the Ministry of Education in the early 50's. It was stated to develop a system for studying advanced pedagogical experience in the country.

After analyzing the state of affairs, S.Chavdarov came to the conclusion that the problem of generalization and implementation of advanced pedagogical experience was solved unsatisfactorily. In addition, he noted that pedagogical scientists were cut off from life and did not help schools and teachers with disabilities. S.Chavdarov's conclusion was based on the opinion of K. Ushinsky that the experience can not be transferred but the idea is derived from experience. That, according to the scientist, provided a creative approach to the achievements of teachers and teaching staff.

The reorganization of the school (1958-1960) and its further development set new requirements for education. Thus, "The methods of teaching the Ukrainian language in school" edited by S.Chavdarov and V.Masalsky which was published in 1962 made a significant contribution to the theory and practice of language teaching [6-7]. This work 
basically completed the scientifically sound and pedagogically justified system of language teaching at school. It should be emphasized that the manual was written on the basis of theoretical understanding of the best methodological achievements, as well as the authors' own great experience in high school.

The authors were able to define the essence of methodology as a science, principles, content, methods and techniques in arming students with a system of knowledge, skills and practical skills in grammar, orography, punctuation and stylistics. It became the last work of the scientist's creative work.

Conclusion. Based on the study of pedagogical, historical, historical-pedagogical, philosophical, historicalpsychological, socio-philosophical literature, conclusions are made about the dynamics of the development of pedagogical views of S.Chavdarov. They are inseparable from the era in which the scientist lived (first half of the twentieth century). This is a period of reforms that took place in all spheres of Ukrainian society: economic, political, sociocultural.

The formation of S.Chavdarov's scientific worldview took place under the influence of socio-cultural factors, the evolution of social ideas, the development of history, sociology, political science, culture, ethics, religion. It is the imperatives that determined the systematization and semantic structuring of the author's vision of the methodology of studying school subjects, in particular the Ukrainian language. The sources of S.Chavdarov's scientific and pedagogical concept were: classical pedagogical thought, ele- ments of folk pedagogy, official Soviet ideology, progressive ideas of the modern author of the theory and practice of education and upbringing, etc.

The problems outlined by the great scientist-educator are still extremely relevant for modern Ukrainian school. A feature of S.Chavdarov's methodical work is his vision not only of the problems of didactics, but also of the psychology of students' thinking development. He believed that forms and methods of teaching should be aimed at helping students develop independent judgment. S. Chavdarov considered independence to be the end result of the studies. His main thesis was: society needs a person who is able to think independently. All scientific and methodical activity of S.Chavdarov contributed to the improvement of learning the native language by millions of people. His advice and recommendations are still widely used not only by language teachers, but also by other scholars in the process of creating programs, textbooks, manuals. The study of his didactic heritage deepens and enriches the scientific principles on which it is possible to successfully build the entire system of teaching the Ukrainian language in schools of Ukraine.

The experience of the Honored Scientist, Corresponding Member of the Academy of Pedagogical Sciences of the RRFSR, Professor S.Chavdarov in organizing the education and upbringing of students can be successfully used by foreign colleagues in their practice in creating textbooks, manuals and various methodological developments for learning the native language.

\section{ЛIТЕРАТУРА}

1. Алексюк А.М. Невтомний розвідник педагогічних глибин / А. М. Алексюк // Рад. школа. 1967. № 8. С. 95-99.

2. Чавдаров С.Х. Пунктуаційна техніка учнів трудшкіл /C.X. Чавдаров // Шлях освіти. 1930. № 4. С. 141-155: табл.

3. Чавдаров С.Х. Чергові завдання у викладанні мови в школі /С.Х. Чавдаров // Комуніст. освіта. 1934. № 10. С. 25-40: табл. Бібліогр. у підрядк. прим.

4. Чавдаров С.X. Методика викладання української мови (граматики і правопису) в середній школі / С.Х.Чавдаров. К.; Х.: Рад. школа, 1939. 183c.

5. Чавдаров С.X. Принципи радянської дидактики / С.Х.Чавдаров. К.,1949. 92 с.

6. Методика викладання української мови (граматики i правопису) в середній школі. К.; Х.: Рад. школа, 1939. 183 c.

7. Методика викладання української мови в середній школі / [C.Х. Чавдаров, В. І. Масальський; у перероб. частин кн. брали участь Г. І. Купрієнко, А. П. Медушевський, М. В. Павлович]; Укр. наук.-дослід. ін.-т педагогіки; за ред. С. Х. Чавдарова і В. І. Масальського. К.: Рад. школа, 1954. 345с.

8. Як викладати граматику i правопис української мови в початковій школі 3 українською мовою викладання (по стабільному підручнику С. Чавдарова і П. Волинського) / С. Чавдаров і П. Волинський. Х.: Рад. школа, 1934. 59, [1] c. (Методичні поради вчителеві початкової школи). На обкл. назва: Як викладати українську мову в початковій школі з українською мовою викладання.

9. Теорія та історія педагогіки//Народна освіта і педагогічна наука в Українській РСР 1917-1967. Радянська школа. 1967. С.285-420.

\section{REFERENCES}

1. Aleksyuk, A.M. Tireless scout of pedagogical depths / A.M. 7. Methods of teaching the Ukrainian language in high school / Aleksyuk // Rad. school. 1967. № 8. P. 95-99.

2. Chavdarov, S.H. Punctuation technique of students of labor schools /S.H. Chavdarov // The way of education. 1930. № 4. P. 141-155: tabl.

3. Chavdarov, S.H. The next tasks in language teaching at school /S.H. Chavdarov // Communist. education. 1934. № 10. P. 2540: tabl. Bibliogr. in the substring. approx.

4. Chavdarov, S.H. Methods of teaching the Ukrainian language (grammar and spelling) in high school / SH Chavdarov. K.; H.: Glad. school, 1939. 183p.

5. Chavdarov, S.H. Principles of Soviet didactics / S.H. Chavdarov. - K., 1949. - 92 p.

6. Methods of teaching the Ukrainian language (grammar and spelling) in high school. K.: Sov. school, 1939. 183 c.

[S.H.Chavdarov, V.I. Masalsky; G.I.Kuprienko, A.P.Medushevsky, M.V.Pavlovich participated in processing. parts of the book]; Ukr. research in-t pedagogy; for order. S.H. Chavdarov and V.I Masalsky. K.: Sov. school, 1954. 345p.

8. How to teach grammar and spelling of the Ukrainian language in elementary school with the Ukrainian language of teaching (on the stable textbook of S.Chavdarov and P.Volynsky )"/S. Chavdarov and P. Volynsky. Sov. school, 1934. 59 p. (Methodological advice to the primary school teacher). How to teach Ukrainian in elementary school with the Ukrainian language of teaching.

9. Theory and history of pedagogy // Public education and pedagogical science in the Ukrainian SSR 1917-1967. Soviet school. 1967. P. 285-420. 